Florida International University FIU Digital Commons

\title{
The Relationship Between Water Level, Prey Availability and Reproductive Success in Roseate Spoonbills Foraging in a Seasonally-Flooded Wetland While Nesting in Florida Bay
}

Jerome J. Lorenz

Audubon Florida Tavernier Science Center, jlorenz@audubon.org

Follow this and additional works at: https://digitalcommons.fiu.edu/fce_lter_journal_articles

Part of the Earth Sciences Commons

\section{Recommended Citation}

Lorenz, J.J.. 2013. The Relationship Between Water Level, Prey Availability and Reproductive Success in Roseate Spoonbills Foraging in a Seasonally-Flooded Wetland While Nesting in Florida Bay. Wetlands DOI: 10.1007/s13157-012-0364-y

This material is based upon work supported by the National Science Foundation through the Florida Coastal Everglades Long-Term Ecological Research program under Cooperative Agreements \#DBI-0620409 and \#DEB-9910514. Any opinions, findings, conclusions, or recommendations expressed in the material are those of the author(s) and do not necessarily reflect the views of the National Science Foundation. This work is brought to you for free and open access by the FCE LTER at FIU Digital Commons. It has been accepted for inclusion in FCE LTER Journal Articles by an authorized administrator of FIU Digital Commons. For more information, please contact dcc@fiu.edu, jkrefft@fiu.edu. 
1 The relationship between water level, prey availability and reproductive success in

2 Roseate Spoonbills foraging in a seasonally-flooded wetland while nesting in Florida

Bay

4 Jerome J. Lorenz: National Audubon Society, Tavernier Science Center, 115 Indian

5 Mound Trail, Tavernier, FL 33070; jlorenz@ audubon.org; 305-852-5092

6

ABSTRACT

8 The coastal wetlands of northeastern Florida Bay are seasonally-inundated dwarf

9 mangrove habitat and serve as a primary foraging ground for wading birds nesting in

10 Florida Bay. A common paradigm in pulse-inundated wetlands is that prey base fishes

11 increase in abundance while the wetland is flooded and then become highly concentrated

12 in deeper water refuges as water levels recede, becoming highly available to wading birds

13 whose nesting success depends on these concentrations. Although widely accepted, the

14 relationship between water levels, prey availability and nesting success has rarely been

15 quantified. I examine this paradigm using Roseate Spoonbills that nest on the islands in

16 northeastern Florida Bay and forage on the mainland. Spoonbill nesting success and

17 water levels on their foraging grounds have been monitored since 1987 and prey base

18 fishes have been systematically sampled at as many as 10 known spoonbill foraging sites

19 since 1990. Results demonstrated that the relationship between water level and prey

20 abundance was not linear but rather there is likely a threshold, or series of thresholds, in

21 water level that result in concentrated prey. Furthermore, the study indicates that

22 spoonbills require water level-induced prey concentrations in order to have enough food

23 available to successfully raise young. 
24 Key Words; Roseate Spoonbill, Florida Bay, prey dependent nesting success, prey

25 concentration threshold, mangrove fishes.

\section{INTRODUCTION}

28 Gawlik (2002) best articulated a widely accepted and well-studied paradigm

29 regarding the function of ephemeral wetlands in determining nesting success of wading

30 birds. In short, during high water periods prey species are relatively less susceptible to

31 predation and their populations grow exponentially and during low water periods, prey

32 are concentrated into lower elevation habitats that provide refuge when ephemeral

33 wetlands are dry. Wading birds exploit the concentrations and time nesting and nest

34 location so that there is a readily available food source for the rapidly growing and

35 energetically demanding young and that this availability must be sustained through the

36 entire nesting cycle. While most components of this paradigm have been demonstrated

37 empirically (Kahl 1964, Higer and Kolipinski 1967, Kushlan 1976a, Kushlan 1978,

38 Kushlan 1980, Ogden et al. 1980, Loftus and Kushlan 1987, Powell 1987, Frederick and

39 Colopy 1989, Loftus and Eklund 1994, Bancroft et al. 1994, Frederick and Spalding

40 1994, DeAngelis et al. 1997, Lorenz 2000, Gawlik 2002, Herring et al. 2011) the

41 connection between water level/prey availability and nesting success has been somewhat

42 elusive. Because nesting sites and foraging locations are spatially distant and the location

43 of foraging sites changes temporally as a patch of concentrated prey is depleted, it is

44 difficult to determine prey abundance at specific sites where a particular pair of

45 successfully nesting birds foraged. Furthermore, there could be nesting failure unrelated

46 to food availability (e.g. predation, disease, weather, human disturbance etc.). 
Another challenge in demonstrating this connection is that the relationship

48 between low water levels and prey availability is likely to be non-linear. For example,

49 high fish concentrations can arise when water levels are relatively high due to oxygen and

50 thermal stress that drive prey from wetlands into deeper water (e.g. Frederick and Loftus

51 1993). Conversely, prey availability can be low when water levels are low due to

52 depletion of prey from predation and/or effects of overcrowding (e.g. Gawlik 2002) or

53 hydrologically-limited productivity (e.g. Lorenz 2000). Although the linearity of the

54 relationships between water level, prey availability and nesting success are investigated

55 here, the analyses also focus on the concept of a Prey Concentration Threshold (PCT). I

56 propose that prey concentrations do not adhere to a strictly-linear relationship with water

57 level, rather, there is some water depth (the PCT) at which prey will abandon the

58 ephemeral wetlands and move to deep water refuges prior to the wetlands drying out

59 entirely. When water levels drop to this point, there is short-lived pulse in prey

60 concentrations as all the prey flee the drying wetland en masse. These concentrated prey

61 are then are quickly depleted through predation and other mortality factors.

62 I address this paradigm using 22 years of Roseate Spoonbill (Platalea ajaja)

63 nesting data from colonies on islands in NEFB and water level and prey (demersal fish)

64 data from multiple foraging sites located in mainland mangrove wetlands specifically to

65 1) test the linearity of the relationships between water level, prey availability and nesting

66 success, 2) investigate the concept of the PCT, and 3) to investigate whether prey

67 availability has a direct impact on nesting success in a wading bird species.

68 Roseate Spoonbills were extirpated from Florida by the early 1900's due to

69 overhunting to provide feathers to the fashion industry (Allen 1942). Legal protection 
70 resulted in population recovery and by the late 1970's the population had recovered to

71 more than 1200 nests in Florida Bay (Powell et al. 1989), more than half of which were

72 located in extreme northeastern corner of Florida Bay (Fig. 1; Lorenz et al. 2002). In

73 1984, the completion and operation of a series of canals and pumps (known as the South

74 Dade Conveyance System or SDCS) had a profound impact on the way fresh water

75 flowed into northeastern Florida Bay (NEFB). Prior to the SDCS, most of the fresh water

76 flowed from the Everglades into Florida Bay via Taylor Slough and associated creeks to

77 the east (Fig. 2). The SDCS diverted water away from Taylor Slough and into the C-111

78 canal (Fig. 2), fundamentally altering the hydrology of Taylor Slough and NEFB (Kotun

79 and Renshaw this issue). Since completion of the SDCS, notable changes have been

80 observed in the flora and fauna of Florida Bay, particularly in the northeastern region

81 (Lorenz, this issue) and spoonbill numbers in NEFB have been drastically reduced, with

$82<50$ pairs in 2008-09 (Fig. 1; Lorenz and Dyer 2010).

\section{METHODS}

85 Wetland Site Description.

86 Spoonbills nesting in NEFB primarily forage in the seasonal ephemeral mangrove

87 wetlands north of the Bay from Taylor Slough eastward to Turkey Point (Fig. 2; Bjork

88 and Powell 1994, Lorenz et al. 2002, Lorenz unpublished satellite tracking data). The

89 mainland wetlands of NEFB are dwarf mangrove habitat, characterized by a centralized

90 creek ("creek" sub-habitat) that contains water throughout the year that is surrounded by

91 expansive shallow flats ("flats" sub-habitat) that are ephemerally inundated (Figure 2).

92 Vegetation consists of widely spaced (0.5-5.0 m) dwarf red mangrove (Rhizophora 
93 mangle) trees (0.5-2.0 m tall) with varying amounts of herbaceous vegetation between

94 individual trees. Seasonal growth of Eleocharis cellulosa, Utricularia spp. and Chara

95 hornimani is common and the substrate is flocculent, unconsolidated, carbonate marl

96 (Browder et al. 1994).

97 There is a characteristic seasonal pattern to the water level fluctuations on these

98 wetlands, with high water levels that inundate the ephemeral wetlands during the wet

99 season (June-Nov) and low water during the dry season (Dec-May) that exposes the

100 ephemeral wetland and results in only the central creeks being inundated (Lorenz 1999).

101 The principle drivers of this long-term cycle are the thermal expansion and contraction of

102 the Gulf of Mexico (Marmar 1954, Holmquist et al 1989) and wet season/dry season

103 rainfall patterns (Duever et al. 1994). Because the onset of the rainy season provides a

104 natural break in the cycle (Lorenz and Serafy 2006), "hydroyear" is defined from June 1

105 to May 31. Wind-driven tides can increase or decrease water levels (up to $40 \mathrm{~cm}$ ) on the

106 wetlands very quickly and those conditions can be maintained until cessation of the wind

107 event (Holmquist et al. 1989). Upstream water management practices, such as pulse

108 releases from the C-111 canal (Fig. 2), can also result in rapid increases in water levels

109 (Kotun and Renshaw this issue, Lorenz this issue) that may endure for several days. The

110 southern Biscayne Bay wetlands are generally unaffected by these pulse releases as water

111 flow through the C-111 canal is blocked near US Highway 1 (US1; Fig. 2), so the

112 majority of water released through the $\mathrm{C}-111$ flows southward from the canal on the west

113 side of US-1 toward Florida Bay (Kotun and Renshaw this issue, Lorenz this issue).

114 Finally, diurnal tides affect water levels on the wetlands of southern Biscayne Bay, 
115 although the amplitude is relatively small (9-15 cm; Lorenz 1999); there are no diurnal

116 tides on the NEFB wetlands (Lorenz 1999).

118 Data Collection

119 Water Level Records. Water level recorders were placed at ten known spoonbill

120 foraging locations in the NEFB wetlands and west of southern Biscayne Bay (Fig. 2).

121 Hydrostations recorded depth (hourly) relative to the elevation of the flats (i.e., a reading

122 of $0 \mathrm{~cm}$ on the recorder indicated that the flats were completely dry while the creek was

123 flooded). Establishment of these sites was staggered through time but are identified as

124 long-term (established prior to 1992) mid-term (established in early 2000s) and short-

125 term (established after 2005; dates of the establishment of sites are presented in the ESM

126 1). Prior to 2000 , data were collected using a Telog ${ }^{\circledR} 2108$ potentiometric recorder with

127 a float and pulley design. After 2000, telemetered hydrostations (Remote Data Inc.,

128 using Hydrolab ${ }^{\circledR}$ pressure sensors to record water depth on a remotely-accessible

129 Campbell ${ }^{\circledR}$ data recorder) were established at each site in addition to the Telog ${ }^{\circledR}$

130 recorders, thereby creating redundancy in water level data collection. Gaps in the data

131 were filled by using regression models between nearby hydrostations (see ESM 1 for

132 further details).

133 Prey Fish Sampling. Drop traps were used to collect fish according to the

134 methodology of Lorenz et al. (1997). Three $9-\mathrm{m}^{2}$ traps were used in each sub-habitat

135 (creek and flats) at each site. Each trap surrounded an individual dwarf mangrove tree,

136 thereby sampling both prop root habitat and the open area between trees (Fig. 2). Trees

137 were selected for sampling such that each site had a similar array of tree sizes with 
138 roughly equivalent prop root density sampled between sites. Traps were set, left in place

139 overnight and deployed the following day within $2 \mathrm{~h}$ after sunrise. Fish were cleared from

140 the trap using rotenone. Traps remained in place until the following day and any fish

141 found floating within the trap were added to the sample and their weights were estimated

142 from length-weight regressions generated from fishes from the initial collection (Lorenz

143 et al. 1997). Sample collections were targeted for June, September, and monthly from

144 November through April, however, logistical, economical and climatological problems

145 prevented complete sampling at some sites (presented in ESM 1). The majority of fish

146 collections were made during the dry season and transitional periods so that the impact of

147 fluctuations in water level could be assessed.

148 Although the drop traps were specifically designed to catch the small demersal

149 fishes that are the primary prey items of spoonbills (Lorenz et al., 1997), incidental

150 collections of larger fishes did occur. In some cases, a single large individual weighed

151 more than the entire sample of smaller fishes. Length-frequency distributions indicated

152 that all fish found on the flats were $<6.5 \mathrm{~cm}$ TL (total length). The flats made up the

153 majority of the habitat, indicating that fish larger than $6.5 \mathrm{~cm}$ TL were not an integral part

154 of the demersal fish community. Based on this observation, all fish $\geq 6.5 \mathrm{~cm}$ TL (3.2\% of

155 total fish collected) were omitted from analyses. The elimination of these large fish

156 limits the data to prey that spoonbills are likely to capture, as spoonbills' principle diet is

157 fish up to approximately $5 \mathrm{~cm}$ (Dumas 2000).

158 Spoonbill nesting colony surveys. Spoonbills typically nest in Florida Bay

159 between November and April (Powell et al. 1989). During this period, nest production

160 was estimated by repeated visits to a given colony on a 7-10 d cycle. Up to 65 nests were 
161 marked with uniquely numbered nest tags during the late incubation period. An estimate

162 of the mean hatch day was made based on chick size and morphology when they were

163 first observed. At approximately $21 \mathrm{~d}$, chicks begin to move out of the nest and spend

164 their time in adjacent trees (Allen 1942, Dumas 2000, Lorenz et al. 2002) and surveys

165 must be discontinued for the safety of the chicks (susceptible to falling out of the trees

166 when disturbed). Chicks that made it to $21 \mathrm{~d}$ (from here referred to as the nestling

167 period) were considered successful even though some mortality does occur after they

168 leave the nest.

169 Spoonbill nest success surveys were performed at Tern Key (historically the

170 largest colony in NEFB) during every nesting cycle from 1987-88 to 2006-07 except for

171 1993-94. Beginning in 2007-08, the Tern Key colony failed to form so several smaller

172 colonies near Tern Key were surveyed in 2007-08 and 2008-09. No individual nest data

173 were available for the years 1988-89, 1991-92, 1992-93 and 1994-95 (for various

174 reasons), however, summary statistics for mean hatch date and mean nest production

175 were available. In most years a small number of spoonbills will nest a second time but in

176 1998-99, and from 2001-02 to 2005-06, the second nesting effort was sizable (almost as

177 large or larger than the first nesting). These second nestings were surveyed using the

178 above techniques as well, and treated the same as the first nestings.

$180 \quad$ Data Analysis

181 Prey availability. Average density and biomass of fish were calculated for each

182 sub-habitat (creeks and flats) at each site. The mean number of prey/trap from the sub-

183 habitat with the largest number of prey collected was considered the estimate of available 
184 prey. The direct use of prey availability (i.e., abundance or biomass $\mathrm{m}^{-2}$ ) is confounded

185 by the fact that each of the sites has a central creek that drains different sized watersheds

186 and sites with larger drainage basins tended to have higher concentrations of fishes than

187 smaller drainage basins. Concentration events would not be isolated to just the drainage

188 in which our sites are located but would be spread over a region that site represents. If

189 the simple estimate of fish density were used than sites with smaller basins would be

190 masked by those with larger ones and it would appear that concentration events never

191 occurred at the sites with smaller basins. In order to standardize the size of the catchment

192 area we relativized each sample to the maximum abundance and biomass for each site.

193 This created an index (on a 0-to-1 scale) for each site, hereby referred to as the fish

194 density availability index or DAI and the biomass availability index or BAI.

195 Prey Concentration Threshold. The mean and standard deviation for all DAI

196 estimates were calculated. All samples collected with a DAI > mean +1 SD were

197 considered to be from a fish concentration event. June or September samples

198 experiencing a concentration event were removed from the estimate of the PCT because

199 the events were likely to be the result of thermal or oxygen stress rather than water level.

200 The tidal sites of southern Biscayne Bay (MB, BS, CS and TP) were also problematic to

201 estimating the PCT. This is because it takes up to $2 \mathrm{~h}$ to deploy all six traps and water

202 level was only collected on an hourly basis so the actual depth at the time of trap

203 deployment is unknown. As a result, concentration events at these sites were also

204 removed from estimating the PCT. For the remaining concentration event samples, the

205 daily mean water level was calculated for the date of the samples. The PCT was defined

206 as the maximum depth at which a concentration event occurred. 
208 defined as the period from $2 \mathrm{~d}$ before the first monitored nest hatched until $2 \mathrm{~d}$ after the

209 last monitored nest had chicks reach $21 \mathrm{~d}$ post-hatch. The nestling period had to be

210 estimated for years for which only the mean hatch date was available (Table 1). The

211 mean difference in days from the first hatch date to the mean hatch date was $9 \mathrm{~d}$ and from

212 the mean hatch date until the last chick reached $21 \mathrm{~d}$ was $40 \mathrm{~d}$ (Table 1). For years with

213 only the mean hatch date available, the first hatch date and the date the last chick reached

$21421 \mathrm{~d}$ were estimated by subtracting $9 \mathrm{~d}$ and adding $40 \mathrm{~d}$, respectively.

215 Mean water depth during the nestling period. For years that individual nests

216 were monitored, the mean water level for the $21 \mathrm{~d}$ post-hatch was calculated for each nest

217 from the long-term water level recording stations. The four years without individual nest

218 data could not be included in calculating mean water depth for individual nests but were

219 used to calculate mean depth for the entire nestling period.

220 Mean DAI and BAI for the nesting period. All fish samples that fell within the

221 nestling period (Table 2) were used to calculate mean DAI and BAI for each nesting

222 cycle. The number of samples collected during each cycle was highly variable with more

223 samples collected as the study went on and fish sampling sites were added. Also, there

224 were different sites used to estimate the DAI and BAI for each cycle, but bias caused by

225 intra-site variation was removed by scaling by the maximum for each site ( 0 to 1 scale).

226 Statistical Analyses. Regressions were used to compare the linearity of water

227 level with prey availability indices, water level with nest production and prey availability

228 indices with nest production. Analysis of variance (ANOVA) was used to compare water

229 levels with nest success (successful=a nest that produces $\geq 1$ chick) and water levels with 
nest production (chicks/nest or $\mathrm{c} / \mathrm{n}$ ) for individual nests. The difference between DAI and

231 BAI for failed and successful nesting cycles were also tested using ANOVA.

\section{RESULTS}

234 Negative relationships were detected between mean water level and both mean

235 nest production $\left(r^{2}=0.41, p<0.001\right)$ and nest success $\left(r^{2}=0.31, p<0.001 ;\right.$ Fig. 3$)$.

236 ANOVA between the number of chicks produced and the mean water level for the

237 nestling period of each individual nest were significant $\left(\mathrm{F}_{4,700}=39.20, \mathrm{p}<0.001\right)$.

238 Individual nests produced between 0 and $4 \mathrm{c} / \mathrm{n}$ and for each incremental increase in

239 production water level was significantly lower (Fig. 4). All assumption for regression

240 models and ANOVA were met.

241 I observed marked inter- and intra-annual variation in water level and

242 corresponding prey abundance and biomass throughout this study's 811 prey sampling

243 events (results of individual collection are presented in the ESM 1). Regression models

244 between water level and fish concentrations were not statistically significant confirming

245 that the relationship between water level and prey availability was non-linear (Fig. 5).

246 The mean and standard deviation of the DAI for these samples was 0.182 and 0.187

247 respectively. There were forty samples with a DAI greater than the mean plus one

248 standard deviation (0.369) and qualified for use in estimating the PCT (Table 3). The

249 deepest water level that these concentration samples were collected in was $13.15 \mathrm{~cm}$

250 (collected at JB in April 2000) thereby defined as the PCT.

251 Regressions of the relationship between chick production and prey availability

252 indices had mixed results (Fig. 6). There was a significant linear relationship between 
253 DAI and chick production $\left(\mathrm{r}^{2}=0.34, \mathrm{p}<0.001\right)$ but not between BAI and chick production $254\left(\mathrm{r}^{2}=0.12, \mathrm{p}=0.11\right)$. ANOVA of DAI and BAI between failed (average $\left.<1 \mathrm{c} / \mathrm{n}\right)$ and

255 successful (average $>1 \mathrm{c} / \mathrm{n})$ nesting cycles were significant (DAI: $\mathrm{F}_{(1,20)}=7.78, \mathrm{p}<0.05$;

256 BAI: $\left.\mathrm{F}_{(1,20)}=4.62, \mathrm{p}<0.05\right)$, with successful nesting cycles having a significantly higher

257 degree of available prey (Fig. 7). All assumptions for regression models and ANOVA 258 were met.

\section{DISCUSSION}

261 Results presented here suggest that prey do not concentrate linearly with

262 decreasing water depth, rather, there is a depth threshold at which fish first become

263 concentrated. In the mangrove NEFB wetlands this appears to occur when water levels

264 drop below $\sim 13 \mathrm{~cm}$ on the ephemeral wetland surface (i.e., the PCT). Previous studies

265 have suggested these concentrated prey are rapidly depleted, primarily through predation

266 (e.g., Kahl 1964, Master 1992, Gawlik 2002). These data also indicate that concentration

267 events can occur at water levels as low as $5 \mathrm{~cm}$ below the wetland surface and at

268 numerous depths in between (Table 3). As water levels continue to decline below the

269 PCT, prey that survive the initial concentration event become re-concentrated at lower

270 water, resulting in sequential concentration events at the same location (based on local

271 topography). The concept of thresholds that concentrate fish explains, at least in part,

272 why there is not a linear relationship between water level and fish prey availability. Kahl

273 (1964) presented data that support the concept of a water level threshold for

274 concentrating prey. He indicated that a $6 \mathrm{~cm}$ drop in water levels at a Wood Stork

275 (Mycteria american) foraging site increased the density of prey fish from $50 \mathrm{~m}^{-2}$ to $\sim 2000$ 
$276 \mathrm{~m}^{-2}$. After dropping another $6 \mathrm{~cm}$, the density remained about the same (2200 fish $\left.\mathrm{m}^{-2}\right)$.

277 This suggests that, at some level between the first and second recession events fish were

278 forced to leave the adjacent wetland.

279 The regression results relating water level with nesting success concur with

280 numerous other studies that, in southern Florida, nesting wading birds have a greater

281 degree of nesting success at lower water levels (Kahl 1964, Frederich and Collopy 1989,

282 Powell et al. 1989, Ogden 1994, Hoffman et al 1994, Bancroft et al. 1994, Frederick and

283 Spaulding 1994, Lorenz et al. 2002). The estimation of the PCT at about $13 \mathrm{~cm}$

284 augments the results of the ANOVA of water level and nest production (Fig. 4) since

285 failed nests had a mean water level and standard error above the PCT. Nests producing 1

$286 \mathrm{c} / \mathrm{n}$ also had a mean just above the PCT but the standard error that spans below the PCT.

287 Nests that produced 2, 3 and $4 \mathrm{c} / \mathrm{n}$ were foraging under conditions where the mean water

288 level and standard error were below the PCT, and each incremental increase in

289 productivity had significantly lower water level.

290 There was a linear relationship between DAI and nest production but not BAI and

291 nest production (Fig. 6). Lorenz and Serafy (2006) documented that, at these sampling

292 locations, the assemblage of fishes present is a better determinant of biomass than the

293 density of fish present. Furthermore, they documented that salinity was the major

294 determinant of the community structure with communities from lower salinity

295 environments having larger biomass. Although it is intuitive that higher biomass should

296 be more important than the total density of available fish for determining nest

297 productivity, it is the density of fish that determines whether there is a concentration

298 event or not. The fact that fish are concentrated at these sites may suggest that fish 
299 further upstream in lower salinity environments may be concentrated as well. These

300 would have higher biomass and would also be readily exploited by nesting spoonbills.

301 Thus, the fact that fish are concentrated may be a better indicator that foraging conditions

302 are better throughout the landscape than the biomass that is available at these particular

303 locations and times.

304 The ANOVA of DAI and BAI between failed and successful nesting cycles

305 demonstrated that prey were more available during nesting cycles that resulted in an

306 average of greater than $1 \mathrm{c} / \mathrm{n}$ than those that produced less than $1 \mathrm{c} / \mathrm{n}$ (Fig. 7). These

307 results, in addition to the DAI regression model (Fig. 6) support the relationship between

308 available prey on the primary foraging grounds with the ability of spoonbills nesting on

309 islands in NEFB to raise chicks through the critical $21 \mathrm{~d}$ post hatch period.

310 Studies that relate water level to nesting success express or imply that this is the

311 result of prey becoming more available to wading birds at lower water levels (Ogden et

312 al. 1980, Powell, 1987, Frederick and Collopy 1989, Frederick and Spalding 1994, Ogden

313 1994) however, few studies present any prey availability data. Conversely, many studies

314 demonstrate that wading birds forage more successfully in areas where fish have been

315 concentrated (Kahl 1964, Kushlan 1976b, Master 1987, Master 1989, Gawlik 2002), but

316 rarely can this foraging success be related back to the success or failure of a specific

317 colony or population although it is commonly inferred. Previous studies have

318 demonstrated that spoonbills nesting in NEFB primarily forage in the wetlands where I

319 measured water levels and collected prey samples (Bjork and Powell 1994, Lorenz et al.

320 2002, Lorenz unpublished satellite tacking data). By surveying spoonbill colonies so as

321 to know nest production and identify the nestling period and by using numerical indices 
322 of prey collected on their primary foraging grounds during the nestling phase, links

323 between lower water levels, greater prey availability and higher nest production were

324 demonstrated.

325 Lorenz et al. (2002) demonstrated that, prior to anthropogenic alterations to the

326 foraging habitats of Florida Bay, spoonbills produced an average of $2.25 \mathrm{c} / \mathrm{n}$, resulting in

327 an exponential increase in the number of spoonbill nests in Florida Bay. Since the

328 completion of the SDCS in 1984, the average production has been $0.98 \mathrm{c} / \mathrm{n}$ (Table 1). De

329 le Court and Aguilera (1997) indicated that Eurasian Spoonbills (Platalea leucordia)

330 exhibit nesting fidelity to their natal colony location and that their is only a small degree

331 of gene flow between discrete nesting populations. Similarly, I have found that Roseate

332 Spoonbills in Florida likely occur in discrete nesting populations that are largely insular

333 when it comes to immigration and emigration (unpublished banding and tracking data). It

334 appears that the conditions that result in a production rate of $<1 \mathrm{c} / \mathrm{n}$ are not able to sustain

335 NEFB's population thereby explaining the striking decline in nest numbers (Fig. 1).

336 Results indicate that if water management practices result in a reversal of the dry

337 down process such that PCT is exceeded during the nestling period, prey will disperse

338 and become unavailable to higher trophic levels. The high energetic demands of rapidly

339 growing wading bird chicks (e.g. Kahl 1964) suggest that nesting attempts will likely fail

340 if prey are unavailable for even a relatively brief period (2-3d). Such reversals have

341 occurred with regularity since the completion of the SDCS (Lorenz 2000), but in the last

342 decade water management practices began to take into account environmental impacts

343 and efforts were made to avoid such reversals. Spoonbill nesting success has been higher

344 since this has happened (Lorenz and Dyer 2010). 
346 lowered wet season and increased dry season water levels in Taylor Slough and that this

347 had similar hydrologic repercussions throughout NEFB. Data presented here indicate

348 these conditions should result in lower prey production during the wet season and less

349 prey availability during the nesting season. Therefore, the water management practices

350 of recent decades likely had a significant role in the depressed nesting success and the

351 declining population of spoonbills in Florida Bay. Given that numerous other species

352 have been similarly affected (Lorenz, this issue) and that spoonbills are an indicator of

353 ecosystem integrity for Florida Bay and the southern Everglades (Lorenz et al. 2009), the

354 current efforts to restore natural flows are necessary and justified.

355 In conclusion, this study demonstrated that the relationship between water level

356 and prey abundance was not linear but rather there is likely a threshold, or series of

357 thresholds, in water level that result in prey concentrations. Furthermore, the study

358 indicates that spoonbills require water level-induced concentrated prey in order to have

359 enough food available to successfully raise young.

\section{ACKNOWLEDGEMENTS}

362 I would like to thank Shawn E. Liston (National Audubon Society) for intellectual

363 contributions as well for the final review. Peter C. Frederick (University of Florida) Dale

364 E. Gawlik (Florida Atlantic University) and the late John C. Ogden also contributed

365 intellectually. I would also like to express gratitude to the myriad dedicated and hard

366 working staff members at TSC that participated in the collection of these data over the

367 last 20 years. 
369 Allen RP (1942) The Roseate Spoonbill. Dover Publications Inc., New York, New York

370 Bancroft GT, Strong AM, Sawicki RJ, Hoffman W, Jewell SD (1994) Relationships

371 among wading bird foraging patterns, colony locations, and hydrology in the

372 Everglades. In: Davis SM, Ogden JC (eds) Everglades: the Ecosystem and Its

373 Restoration. St. Lucie Press, Delray Beach, Florida. pp 615-658

374 Bjork RD, Powell GVN (1994) Relationships between hydrologic conditions and quality

375 and quantity of foraging habitat for Roseate Spoonbills and other wading birds in the C-

376111 basin. Final report to the South Florida Research Center, Everglades National

377 Park, Homestead, Florida

378 Browder JA, Gleason PJ, Swift DR (1994) Periphyton in the Everglades: spatial

379 variation, environmental correlates and ecological implications. In: Davis SM, Ogden

380 JC (eds) Everglades: the Ecosystem and Its Restoration. St. Lucie Press, Delray Beach, $381 \quad$ Florida, p 379-418

382 DeAngelis DL, Loftus WF, Texler JC Ulanowicz RE (1997) Modeling fish dynamics and 383 effects of stress in a hydrologically pulsed ecosystem. Journal of Aquatic Ecosystem

384 Stress and Recovery 6:1-13

385 De la Court C, Aguilera E (1997) Dispersal and migration in eurasian spoonbills. Ardea $386 \quad 85: 193-202$

387 Duever, MJ, Meeder JF, Meeder LC, McCollom JM (1994) The climate of south Florida 388 and its role in shaping the Everglades ecosystem. In: Davis SM, Ogden JC (eds)

389 Everglades: the ecosystem and its restoration, St. Lucie Press, Delray Beach, pp 225$390 \quad 248$ 
391 Dumas J (2000) Roseate Spoonbill (ㅅaa ajaja). In: Poole A, Gill F (eds) The Birds of

392 North America, No. 490. The Birds of North America, Inc., Philadelphia

393 Frederick PC, Collopy MW (1989) Nesting success of five ciconiiform species in relation

394 to water conditions in the Florida Everglades. Auk 106:625-634

395 Frederick PC, Loftus WF (1993) Responses of marsh fishes and breeding wading birds to

396 low temperatures: a possible behavioral link between predator and prey. Estuaries

$397 \quad 16: 198-215$

398 Frederick PC, Spalding MG (1994) Factors affecting reproductive success in wading

399 birds. In: Davis SM, Ogden JC (eds) Everglades: the ecosystem and its restoration, St.

$400 \quad$ Lucie Press, Delray Beach, pp 659-692

401 Gawlik DE (2002) The effects of prey availability on the numerical response of wading

402 birds. Ecological Monographs. 72:329-346

403 Herring G, Cook MI, Gawlik DE, Call EM (2011) Food availability is expressed through

404 physiological stress indicators in nestling white ibis: a food supplementation

405 experiment. Functional Ecology 25:682-690.

406 Higer AL, Kolipinski MC (1967) Pull-up trap: a quantitative device for sampling shallow

407 water animals. Ecology 48:1008-1009

408 Hoffman W, Bancroft GT, Sawicki RJ (1994) Foraging habitat of wading birds in the

409 water conservation areas of the Everglades. In: Davis SM, Ogden JC (eds) Everglades:

410 the ecosystem and its restoration, St. Lucie Press, Delray Beach, pp 585-614

411 Holmquist, JG, Powell GVN, Sogard SM. (1989) Sediment, water level and water

412 temperature characteristics of Florida Bay's grass-covered mud banks. Bulletin of

413 Marine Science 44:348-364 
414 Kahl MP (1964) Food ecology of the wood stork (Mycteria american) in Florida.

$415 \quad$ Ecological Monographs 34:97-117

416 Kotun et al, (this issue of Wetlands) Taylor Slough hydrology: 50 years of water

417 management, 1960-2010

418 Kushlan JA (1976a) Environmental stability and fish community diversity. Ecology

$419 \quad 57: 821-825$

420 Kushlan JA (1976b) Wading bird predation in a seasonally fluctuating pond. Auk

$421 \quad 93: 464-476$

422 Kushlan JA (1978) Feeding ecology of wading birds. In: Sprunt A, Ogden JC, Winckler

423 S (eds) Wading birds: research report no. 7 of the National Audubon Society. National

424 Audubon Society, New York, p 249-299

425 Kushlan JA (1980) Population fluctuations in Everglades fishes. Copeia 1980:870-874

426 Loftus WF, Eklund AM (1994) Long-term dynamics off an Everglades small-fish

427 assemblage. In: Davis SM, Ogden JC (eds) Everglades: the ecosystem and its

428 restoration, St. Lucie Press, Delray Beach, pp 461-483

429 Loftus WF, Kushlan JA (1987) Freshwater fishes of southern Florida. Bulletin of the

430 Florida State Museum of Biological Sciences 31:137-344

431 Lorenz JJ, McIvor CC, Powell GVN, Frederich PC (1997) A drop net and removable

432 walkway for sampling fishes over wetland surfaces. Wetlands 17:346-359.

433 Lorenz JJ (1999) The response of fishes to physicochemical changes in the mangroves of

434 northeast Florida Bay. Estuaries 22:500-517.

435 Lorenz JJ (2000) Impacts of water management on roseate spoonbills and their piscine

436 prey in the coastal wetlands of Florida Bay. Dissertation, University of Miami. 
437 Lorenz JJ, Ogden JC, Bjork RD, Powell GVN (2002) Nesting patterns of roseate

438 spoonbills in Florida Bay 1935-1999: implications of landscape scale anthropogenic

439 impacts. In: Porter JW, Porter KG (eds) The Everglades, Florida Bay and the coral

440 reefs of the Florida Keys: An ecosystem sourcebook, CRC Press, Boca Raton, pp. 555-

441598,

442 Lorenz JJ, Serafy JE (2006) Changes in the demersal fish community in response to

443 altered salinity patterns in an estuarine coastal wetland: implications for Everglades and

444 Florida Bay restoration efforts. Hydrobiologia 569:401-422.

445 Lorenz JJ, Langan-Mulrooney B, Frezza PE, Harvey RG, Mazzotti FJ (2009) Roseate

446 spoonbill reproduction as an indicator for restoration of the Everglades and the

447 Everglades estuaries. Ecological Indicators 9S:S96-S107.

448 Lorenz JJ, Dyer K (2010) Roseate spoonbill nesting in Florida Bay annual report 2009-

449 10. South Florida Wading Bird Report 16:13-16

450 Lorenz JJ (this issue of Wetlands) A review of the effects of altered hydrology and

451 salinity on the vertebrate fauna and their habitats in northeastern Florida Bay.

452 Marmar, HA (1954) Tides and sea level in the Gulf of Mexico. In: Galstoff PS (ed.) Gulf

453 of Mexico, its origin, waters, and marine life. U.S. Fishery Bulletin 89, Washington. pp

$454 \quad 101-118$

455 Master TL (1992) Composition, structure, and dynamics of mixed species foraging

456 aggregations in a southern New Jersey salt marsh. Colonial Waterbirds 15:66-74

457 Ogden JC, Kale HK, Nesbitt SA (1980) The influence of annual variation in rainfall and

458 water levels on nesting by Florida populations of wading birds. Transactions of the

$459 \quad$ Linnaean Society 9:115-126 
460 Ogden JC (1994) A comparison of wading bird nesting colony dynamics (1931-1946 and 461 1974-1989) as an indication of ecosystem condition in the southern Everglades. In:

462 Davis SM, Ogden JC (eds) Everglades: the ecosystem and its restoration. St. Lucie

463 press, Delray Beach, pp 533-570

464 Porter JW, Porter KG (eds) The Everglades, Florida Bay and the coral reefs of the Florida

465 Keys: An ecosystem sourcebook, CRC Press, Boca Raton

466 Powell GVN (1987) Habitat use by wading birds in a subtropical estuary: implications of

467 hydrography. Auk 104:740-749

468 Powell GVN, Bjork RD, Ogden JC, Paul RT, Powell AH, Robertson WB (1989)

469 Population trends in some Florida Bay wading birds. Wilson Bull 101:436-457

470 
472 Table 1. Dates of first hatch, mean hatch and last chick to $21 \mathrm{~d}$ for each nesting cycle.

473 "B" indicates a second nesting cycle in the given hydrologic year.

474 Table 2. Nestling period; mean depth (calculated from the 4 long term data sets), prey

475 Density Availability Index (DAI), prey Biomass Availability Index (BAI) and number

476 of prey samples collected (i.e., number of collections used to calculate the DAI and

477 BAI) for the nestling period; nest production and percent of nests successful.

478 Table 3. Fish collections that were classified as concentration events because they had a

479 DAI greater than the mean +1 standard deviation for all samples collected.

$481 \quad$ Figures

482 Fig. 1. The number of spoonbill nests found for each primary nesting cycle at Tern Key 483 and for all of the colonies in northeastern Florida Bay combined showing the steady

484 decline in nests since the completion of water management infrastructure in 1984.

485 Fig. 2. Top: map showing locations of sites and pertinent landmarks. Bottom: Aerial

486 photo of JB site showing creeks and flats sub-habitats and the fish traps used.

487 Fig. 3. Regression results comparing mean water level from the long-term sites with the 488 nest production (A) and percent of nest successful (B) for each nesting cycle.

489 Fig. 4. ANOVA results comparing mean water levels during the nesting cycle with nest 490 production for each individual nest that was monitored in this study. Number of nests 491 used are provided along the x-axis.

492 Fig. 5. Regression results comparing mean water level from the long-term sites with the 493 DAI (A) and the BAI (B) for each nesting cycle. 
494 Fig. 6. Regression results comparing the DAI (A) and the BAI (B) with nest production 495 for each nesting cycle.

496 Fig. 7. ANOVA results comparing DAI and BAI between failed (mean $<1 \mathrm{c} / \mathrm{n}$ ) and

497 successful (mean $>1 \mathrm{c} / \mathrm{n}$ ) nesting cycles ( $\mathrm{n}=12$ successful cycles and 10 failed cycles). 


\begin{tabular}{|c|c|c|c|c|c|c|}
\hline $\begin{array}{l}\text { Nesting } \\
\text { cycle }\end{array}$ & $\begin{array}{l}\text { Number } \\
\text { of nests } \\
\text { surveyed }\end{array}$ & First Hatch & Mean Hatch & $\begin{array}{l}\text { Last to chick } \\
\text { to } 21 d\end{array}$ & $\begin{array}{c}\text { first hatch } \\
\text { to mean } \\
\text { hatch }(d)\end{array}$ & $\begin{array}{l}\text { mean hatch } \\
\text { to last chick } \\
\text { to } 21 d\end{array}$ \\
\hline $1987-88$ & 60 & 30-Dec-87 & 20-Jan-88 & 21-Feb-88 & 22 & 53 \\
\hline $1988-89$ & & & 12-Dec-88 & & & \\
\hline $1989-90$ & 50 & 20-Dec-89 & 23-Dec-89 & 18-Jan-90 & 3 & 29 \\
\hline $1990-91$ & 37 & 27-Nov-90 & 2-Dec-90 & 1-Jan-91 & 5 & 35 \\
\hline 1991-92 & & & 16-Dec-91 & & & \\
\hline $1992-93$ & & & 1-Jan-93 & & & \\
\hline 1994-95 & & & 5-Mar-95 & & & \\
\hline $1995-96$ & 38 & 14-Dec-95 & 19-Dec-95 & 16-Jan-96 & 6 & 33 \\
\hline $1996-97$ & 24 & 21-Dec-96 & 7-Jan-97 & 9-Feb-97 & 18 & 50 \\
\hline $1997-98$ & 35 & 17-Dec-97 & 22-Dec-97 & 21-Jan-98 & 6 & 35 \\
\hline 1998-99 & 38 & 17-Dec-98 & 22-Dec-98 & 20-Jan-99 & 6 & 34 \\
\hline 1998-99B & 18 & 21-Mar-03 & 30-Mar-03 & 2-May-03 & 9 & 42 \\
\hline $1999-00$ & 24 & 8-Dec-99 & 11-Dec-99 & 5-Jan-00 & 3 & 28 \\
\hline $2000-01$ & 32 & 28-Dec-00 & 31-Dec-00 & 28-Jan-01 & 3 & 31 \\
\hline 2001-02 & 31 & 31-Dec-01 & 3-Jan-02 & 13-Feb-02 & 4 & 44 \\
\hline 2001-02B & 14 & 21-Feb-02 & 27-Feb-02 & 29-Mar-02 & 6 & 36 \\
\hline $2002-03$ & 35 & 13-Dec-02 & 26-Dec-02 & 22-Jan-03 & 14 & 40 \\
\hline 2002-03B & 16 & 26-Jan-03 & 7-Feb-03 & 19-Mar-03 & 12 & 52 \\
\hline 2003-04 & 38 & 30-Dec-03 & 12-Jan-04 & 21-Feb-04 & 14 & 53 \\
\hline 2003-04B & 27 & 4-Apr-04 & 7-Apr-04 & 1-May-04 & 3 & 27 \\
\hline 2004-05 & 15 & 10-Jan-05 & 15-Jan-05 & 7-Feb-05 & 5 & 28 \\
\hline 2004-05B & 7 & 31-Mar-05 & 2-Apr-05 & 24-Apr-05 & 3 & 24 \\
\hline $2005-06$ & 54 & 7-Dec-05 & 17-Dec-05 & 28-Jan-06 & 11 & 52 \\
\hline 2005-06B & 12 & 3-Apr-06 & 11-Apr-06 & 12-May-06 & 8 & 39 \\
\hline 2006-07 & 56 & 14-Dec-06 & 24-Dec-06 & 20-Jan-07 & 11 & 37 \\
\hline 2007-08 & 23 & 29-Nov-07 & 17-Dec-07 & 23-Jan-08 & 18 & 55 \\
\hline 2008-09 & 21 & 17-Dec-08 & 30-Dec-08 & 1-Mar-09 & 14 & 74 \\
\hline Mean & & & & & 9 & 40 \\
\hline
\end{tabular}


Table 2

\begin{tabular}{|c|c|c|c|c|c|c|c|c|c|}
\hline $\begin{array}{l}\text { Nesting } \\
\text { Cycle }\end{array}$ & $\begin{array}{c}\text { Start } \\
\text { Nestling } \\
\text { Period }\end{array}$ & $\begin{array}{c}\text { End } \\
\text { nestling } \\
\text { period }\end{array}$ & $\begin{array}{l}\text { Length of } \\
\text { nestling } \\
\text { period }(d)\end{array}$ & $\begin{array}{c}\text { Mean WL } \\
\text { during } \\
\text { nestling } \\
\text { period }\end{array}$ & $\begin{array}{l}\text { \# prey samples } \\
\text { collected during } \\
\text { nestling period }\end{array}$ & $\begin{array}{c}\text { Mean DAI } \\
\text { during } \\
\text { nestling } \\
\text { period }\end{array}$ & $\begin{array}{c}\text { Mean BAI } \\
\text { during } \\
\text { nestling } \\
\text { period }\end{array}$ & $\begin{array}{c}\text { Mean } \\
\text { Production } \\
\text { (Chicks/nest) }\end{array}$ & $\begin{array}{c}\% \text { of nest that } \\
\text { produced } \\
\text { chicks }\end{array}$ \\
\hline 1987-88 & 28-Dec-87 & 23-Feb-88 & 57 & 16.12 & & & & 1.2 & 0.66 \\
\hline $1988-89$ & 1-Dec-88 & 14-Jan-89 & 44 & 11.18 & & & & 1.9 & \\
\hline $1989-90$ & 18-Dec-89 & 20-Jan-90 & 33 & -0.50 & & & & 2.4 & 0.86 \\
\hline $1990-91$ & 25-Nov-90 & 3-Jan-91 & 39 & 5.67 & & & & 2.2 & 0.77 \\
\hline 1991-92 & 5-Dec-91 & 18-Jan-92 & 44 & 12.91 & 3 & 0.13 & 0.31 & 1.3 & \\
\hline $1992-93$ & 21-Dec-92 & 3-Feb-93 & 44 & 18.20 & 5 & 0.09 & 0.07 & 0 & 0 \\
\hline 1994-95 & 22-Feb-95 & 7-Apr-95 & 44 & 15.34 & 6 & 0.14 & 0.17 & 0 & 0 \\
\hline $1995-96$ & 12-Dec-95 & 18-Jan-96 & 37 & 19.58 & 0 & & & 0.26 & 0.24 \\
\hline $1996-97$ & 19-Dec-96 & 11-Feb-97 & 54 & 15.34 & 4 & 0.21 & 0.27 & 0.25 & 0.25 \\
\hline $1997-98$ & 15-Dec-97 & 23-Jan-98 & 39 & 16.64 & 4 & 0.15 & 0.20 & 0.81 & 0.6 \\
\hline 1998-99 & 15-Dec-98 & 22-Jan-99 & 38 & 19.36 & 4 & 0.18 & 0.16 & 0.35 & 0.38 \\
\hline 1998-99B & 19-Mar-03 & 4-May-03 & 46 & 12.61 & 7 & 0.34 & 0.24 & 2.17 & 0.69 \\
\hline 1999-00 & 6-Dec-99 & 7-Jan-00 & 32 & 19.09 & 4 & 0.06 & 0.09 & 0.64 & 0.32 \\
\hline 2000-01 & 26-Dec-00 & 30-Jan-01 & 35 & 8.52 & 4 & 0.13 & 0.27 & 0.92 & 0.44 \\
\hline 2001-02 & 29-Dec-01 & 15-Feb-02 & 48 & 11.69 & 7 & 0.11 & 0.07 & 1.26 & 0.68 \\
\hline 2001-02B & 19-Feb-02 & 31-Mar-02 & 40 & 8.72 & 5 & 0.09 & 0.14 & 0.61 & 0.39 \\
\hline 2002-03 & 11-Dec-02 & 24-Jan-03 & 44 & 13.07 & 10 & 0.16 & 0.24 & 0.88 & 0.33 \\
\hline 2002-03B & 24-Jan-03 & 21-Mar-03 & 56 & 2.23 & 11 & 0.24 & 0.21 & 0.9 & 0.5 \\
\hline 2003-04 & 28-Dec-03 & 23-Feb-04 & 57 & 14.24 & 14 & 0.17 & 0.17 & 0.14 & 0.08 \\
\hline 2003-04B & 2-Apr-04 & 3-May-04 & 31 & 6.68 & 5 & 0.17 & 0.17 & 1.86 & 0.83 \\
\hline 2004-05 & 8-Jan-05 & 9-Feb-05 & 32 & 13.49 & 9 & 0.14 & 0.19 & 0.18 & 0.07 \\
\hline 2004-05B & 29-Mar-05 & 26-Apr-05 & 28 & 12.65 & 7 & 0.11 & 0.08 & 0.37 & 0.36 \\
\hline 2005-06 & 5-Dec-05 & 30-Jan-06 & 56 & 12.05 & 19 & 0.23 & 0.19 & 1.54 & 0.63 \\
\hline 2005-06B & 1-Apr-06 & 14-May-06 & 43 & 15.22 & 12 & 0.17 & 0.20 & 0.06 & 0.06 \\
\hline 2006-07 & 12-Dec-06 & 22-Jan-07 & 41 & 14.74 & 14 & 0.23 & 0.30 & 0.96 & 0.54 \\
\hline 2007-08 & 27-Nov-07 & 25-Jan-08 & 59 & 12.19 & 21 & 0.29 & 0.29 & 1.6 & 0.96 \\
\hline 2008-09 & 15-Dec-08 & 3-Mar-09 & 78 & 7.03 & 22 & 0.25 & 0.23 & 1.7 & 0.77 \\
\hline Mean & & & & & & & & 0.98 & 0.46 \\
\hline
\end{tabular}


Table 3

\begin{tabular}{ccccc|ccccc}
\hline Hydro $y r$ & month & site & Depth & DAI & Hydro yr & month & site & Depth & DAI \\
\hline $08-09$ & 1 & SB & -4.70 & 0.74 & $07-08$ & 12 & SB & 5.90 & 0.65 \\
$07-08$ & 3 & WJ & -1.76 & 1.00 & $96-97$ & 2 & TR & 6.50 & 0.52 \\
$06-07$ & 2 & SB & -1.63 & 0.89 & $03-04$ & 3 & HC & 6.65 & 0.51 \\
$04-05$ & 2 & SB & -1.58 & 0.89 & $04-05$ & 3 & TR & 6.80 & 0.45 \\
$98-99$ & 3 & HC & -1.50 & 0.95 & $04-05$ & 12 & HC & 7.30 & 0.49 \\
$00-01$ & 2 & TR & -1.28 & 0.51 & $06-07$ & 12 & HC & 7.60 & 0.52 \\
$03-04$ & 1 & HC & 0.17 & 0.47 & $96-97$ & 2 & JB & 8.00 & 0.46 \\
$03-04$ & 4 & HC & 0.42 & 0.50 & $96-97$ & 3 & TR & 8.20 & 0.85 \\
$91-92$ & 4 & HC & 0.50 & 0.38 & $06-07$ & 1 & EC & 8.30 & 0.39 \\
$00-01$ & 3 & TR & 0.74 & 0.53 & $04-05$ & 3 & SB & 8.71 & 0.63 \\
$07-08$ & 12 & HC & 0.96 & 0.41 & $05-06$ & 11 & SB & 9.05 & 0.46 \\
$90-91$ & 12 & HC & 1.07 & 0.39 & $98-99$ & 1 & HC & 9.30 & 0.41 \\
$93-94$ & 1 & HC & 1.40 & 0.74 & $98-99$ & 12 & HC & 9.70 & 0.38 \\
$95-96$ & 3 & TR & 1.72 & 0.47 & $07-08$ & 2 & EC & 10.05 & 0.49 \\
$07-08$ & 3 & EC & 2.10 & 0.87 & $96-97$ & 4 & TR & 10.20 & 1.00 \\
$06-07$ & 2 & EC & 2.88 & 1.00 & $08-09$ & 12 & SB & 10.78 & 0.37 \\
$97-98$ & 4 & HC & 3.00 & 0.39 & $96-97$ & 1 & TR & 10.80 & 0.38 \\
$00-01$ & 4 & TR & 3.58 & 0.40 & $98-99$ & 3 & JB & 11.20 & 0.49 \\
$07-08$ & 3 & SB & 4.70 & 0.42 & $06-07$ & 1 & SB & 11.92 & 0.41 \\
$01-02$ & 4 & HC & 5.05 & 0.44 & $05-06$ & 4 & JB & 13.15 & 1.00 \\
\hline
\end{tabular}




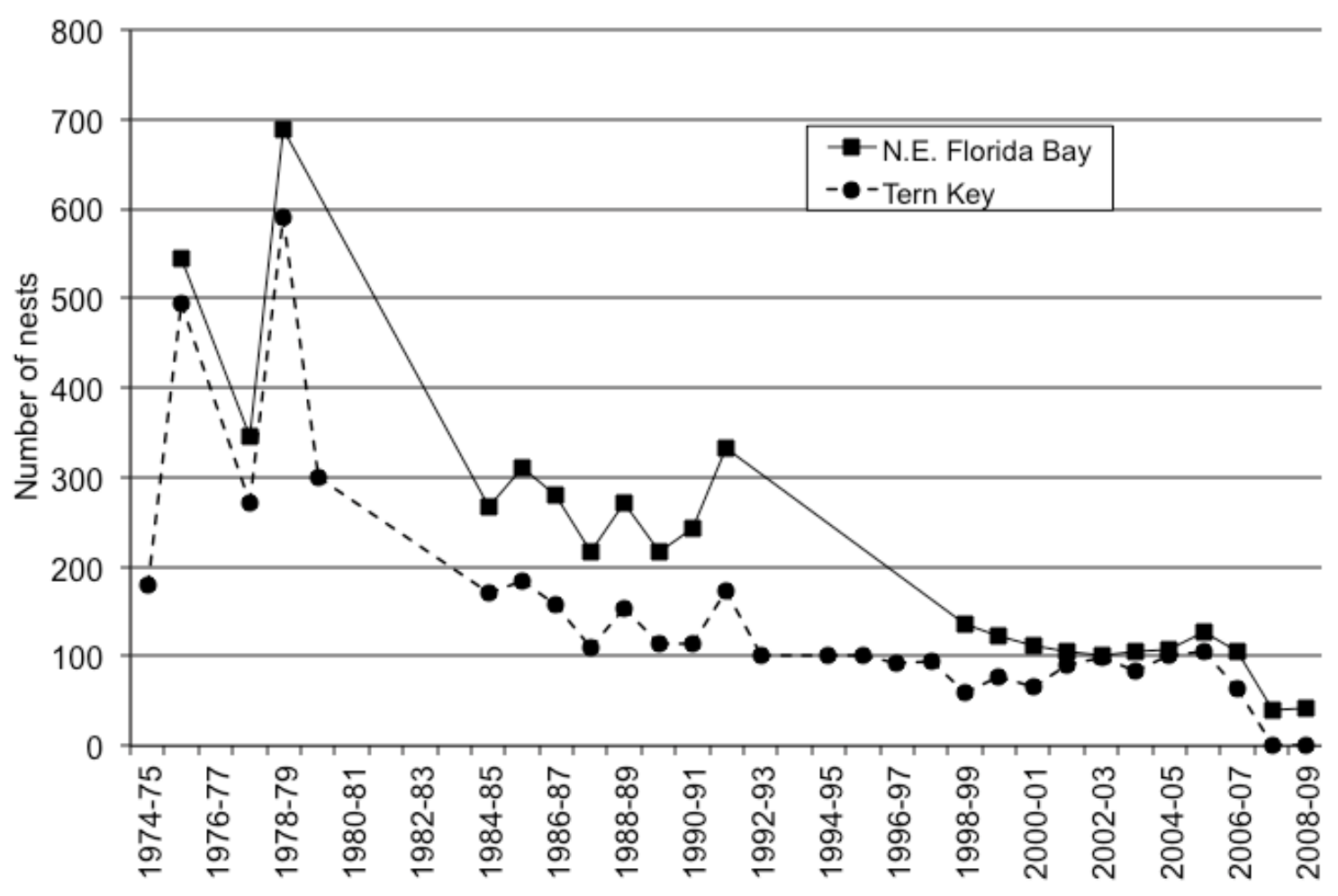

504 Fig. 1 


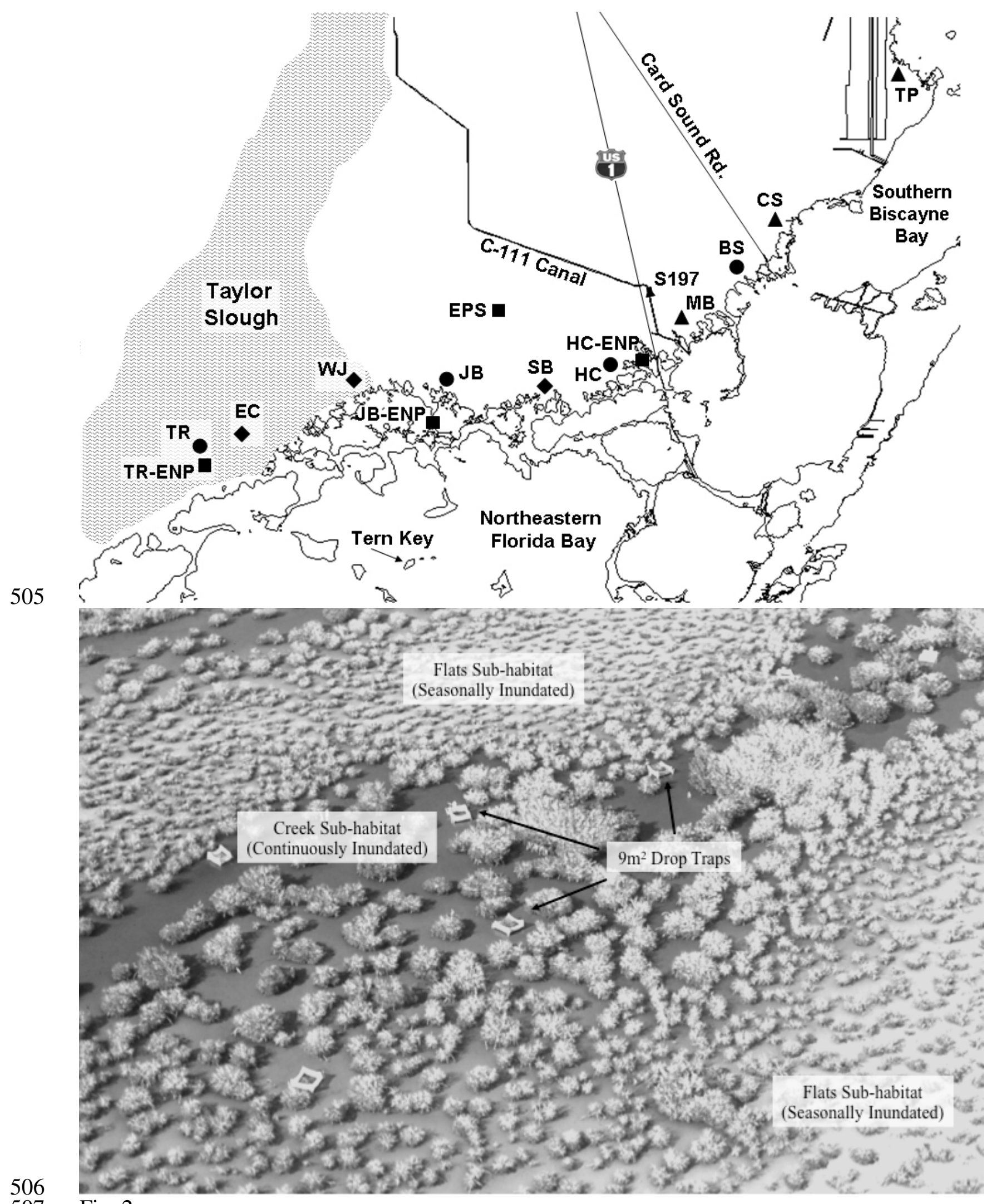

507 Fig. 2 
508
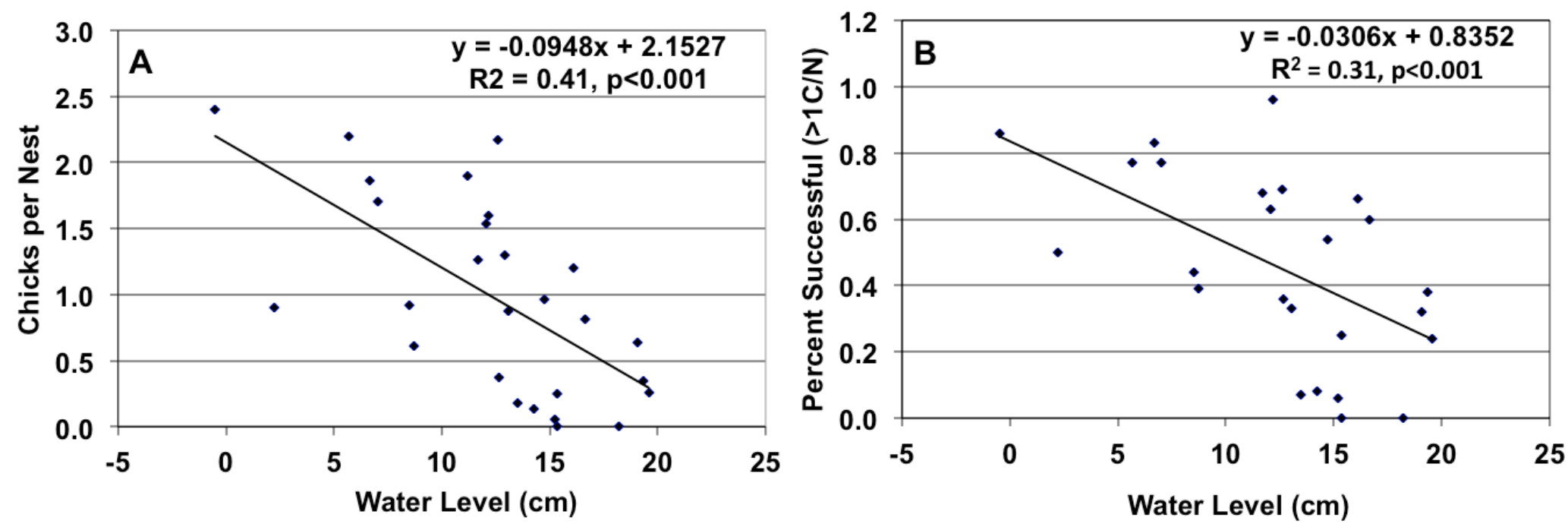

$510 \quad$ Fig. 3

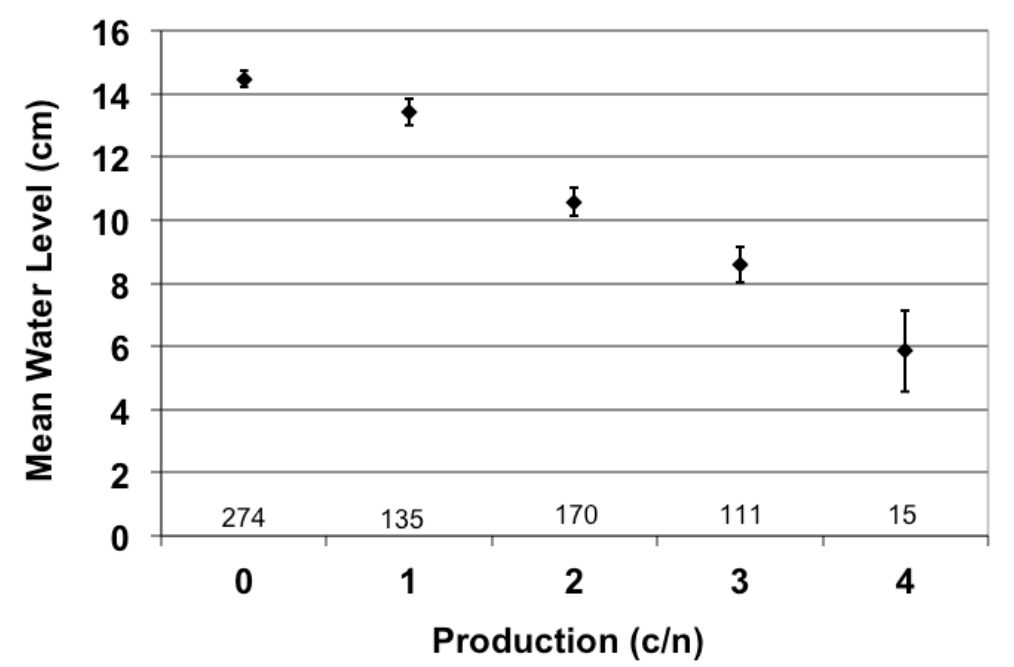

Fig. 4

513 

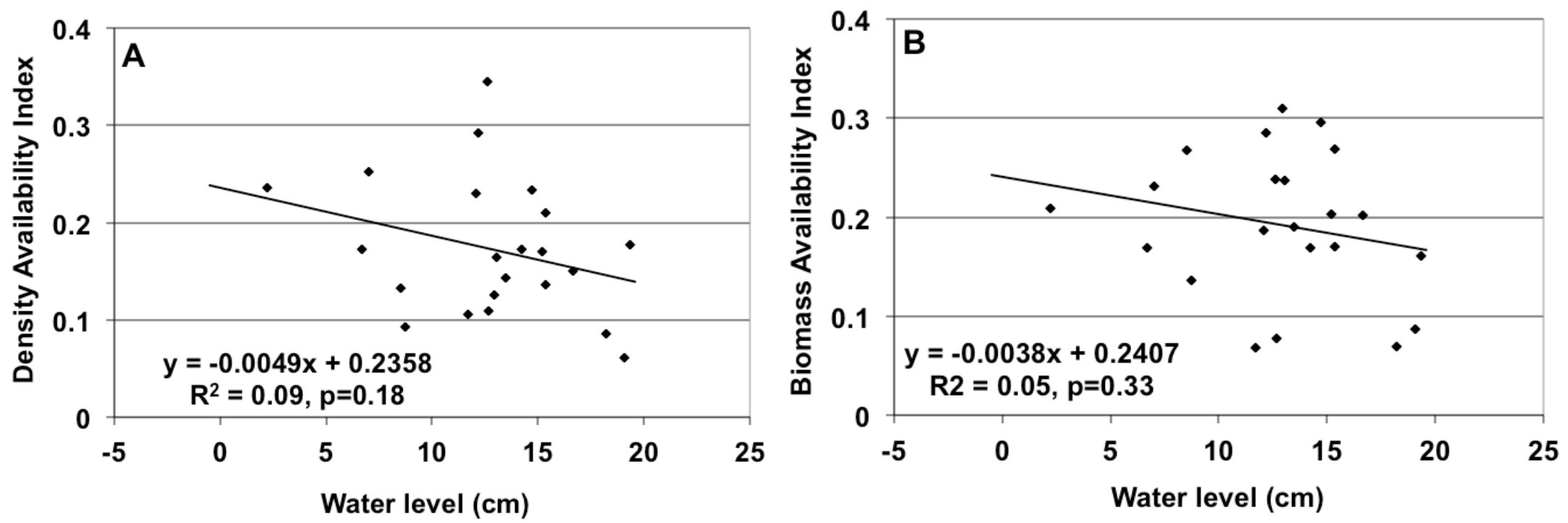

514

515

516

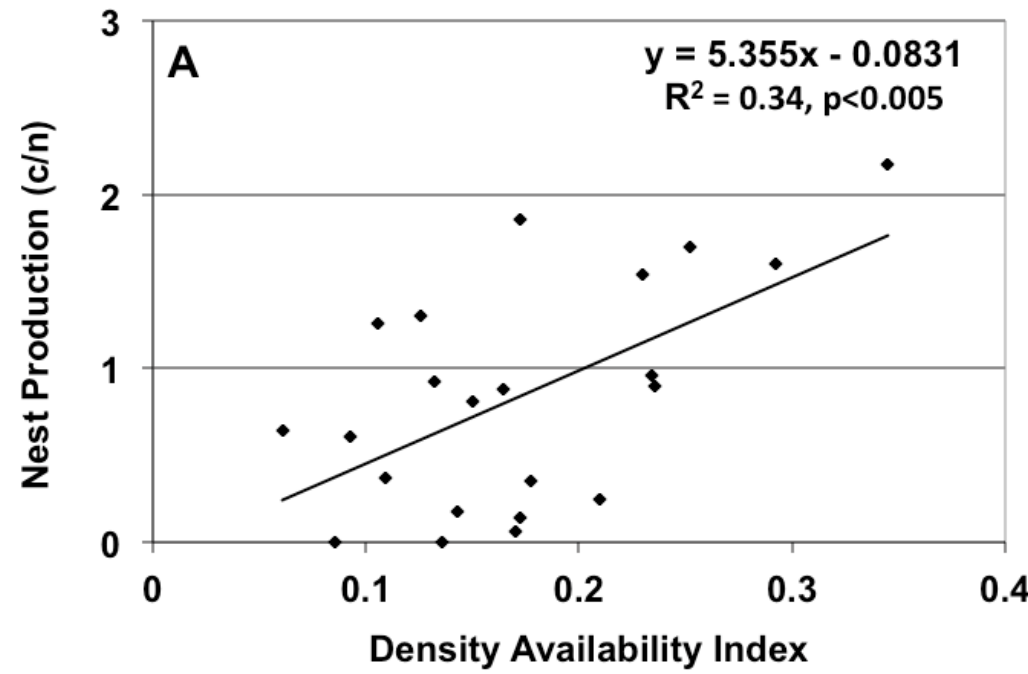

517

$518 \quad$ Fig. 6

Fig. 5.

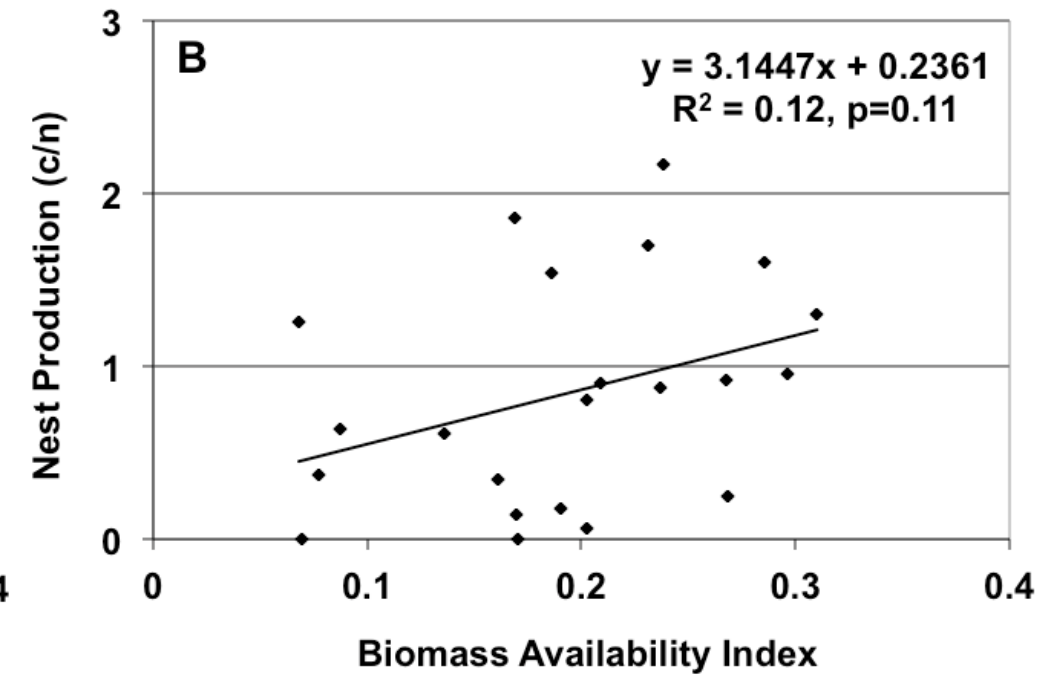




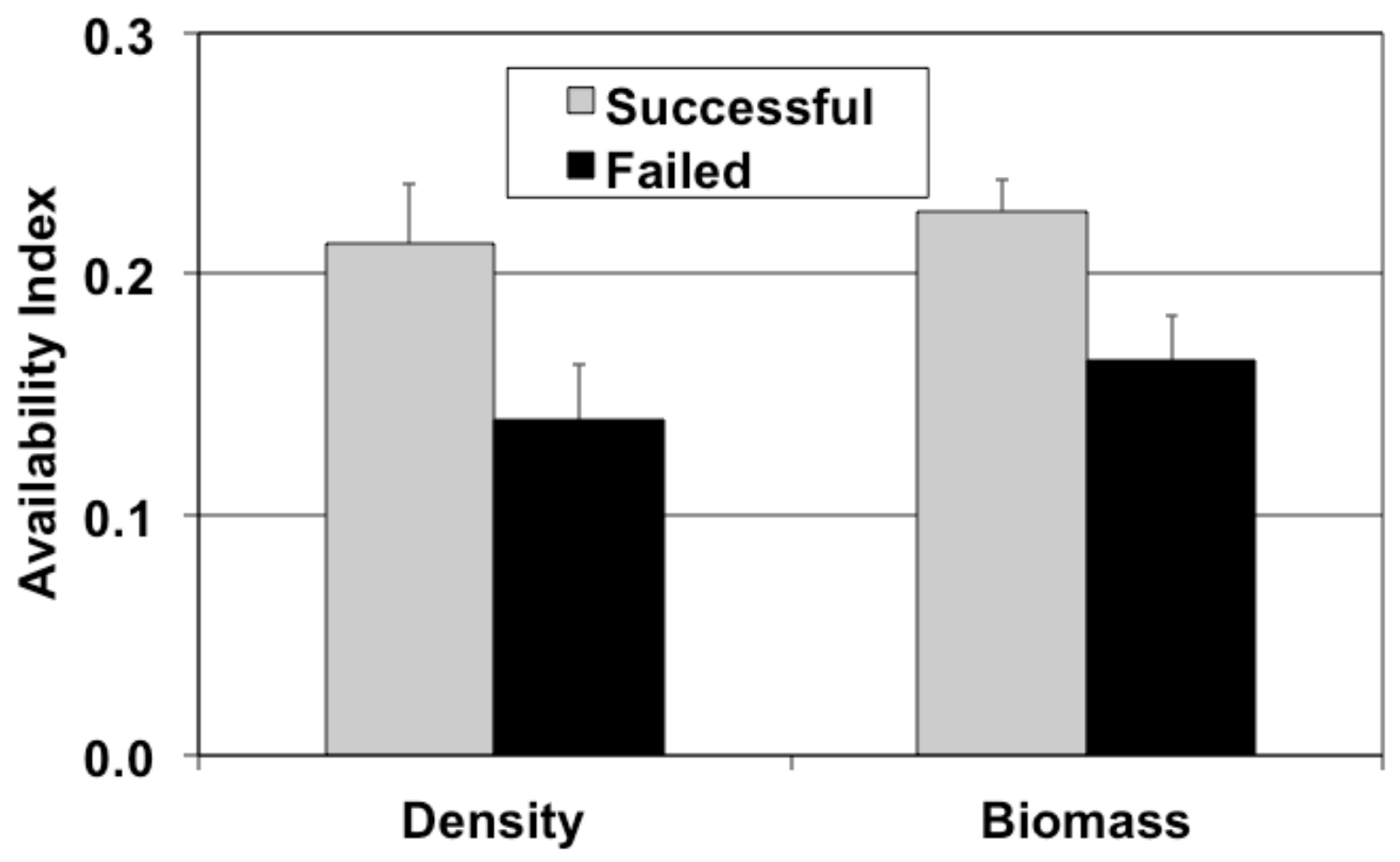

Fig. 7

522 